\title{
Physiological Response and Proteomics Analysis of Reaumuria soongorica Under Salt Stress
}

\author{
Shipeng Yan \\ Gansu Agricultural University \\ Peifang Chong ( 0 976626844@qq.com ) \\ Gansu Agricultural University \\ Ming Zhao \\ Gansu Province Academy of Qilian Water Resource Conservation Forests Research Institute \\ Hongmei Liu \\ Gansu Province Academy of Qilian Water Resource Conservation Forests Research Institute
}

\section{Research Article}

Keywords: Reaumuria soongorica, Salt stress, Indicators of growth, Proteomics, Differential expression

Posted Date: November 30th, 2021

DOI: https://doi.org/10.21203/rs.3.rs-1030695/v1

License: () (i) This work is licensed under a Creative Commons Attribution 4.0 International License. Read Full License

Version of Record: A version of this preprint was published at Scientific Reports on February 15th, 2022. See the published version at https://doi.org/10.1038/s41598-022-06502-2. 


\section{Abstract}

Soil salinity can severely restrict plant growth. Yet Reaumuria soongorica can tolerate salinity well. However, large-scale proteomic studies of this plant's salinity response have yet to reported. Here, $R$. soongorica seedlings ( 4 months old) were used in an experiment where $\mathrm{NaCl}$ solutions simulated levels of soil salinity stress. The fresh weight, root/shoot ratio, leaf relative conductivity, proline content, and total leaf area of $R$. soongorica under CK $(0 \mathrm{mM} \mathrm{NaCl})$, low $(200 \mathrm{mM} \mathrm{NaCl})$, and high $(500 \mathrm{mM} \mathrm{NaCl})$ salt stress were determined. The results showed that the proline content of leaves was negatively correlated with salt concentration. With greater salinity, the plant fresh weight, root/shoot ratio, and total leaf area increased initially but then decreased, and vice-versa for the relative electrical conductivity of leaves. Using iTRAQ proteomic sequencing, 47, 177, 136 differentially expressed proteins (DEPs) were identified in low-salt vs. CK, high-salt vs. control, and high-salt vs. low-salt comparisons, respectively. A total of $72 \mathrm{DEPs}$ were further screened from the groups, of which, $34 \mathrm{DEPs}$ increased and 38 DEPs decreased in abundance. These DEPs are mainly involved in translation, ribosomal structure, and biogenesis. Finally, 21 key DEPs (SCORE value $\geq 60$ point) were identified as potential targets for salt tolerance of $R$. soongolica. By comparing the protein structure of treated vs. CK leaves under salt stress, we revealed the key candidate genes underpinning $R$. soongolica's salt tolerance ability. This works provides fresh insight into its physiological adaptation strategy and molecular regulatory network, and a molecular basis enhancing breeding, under salt stress conditions.

\section{Introduction}

Soil salinization is one of the main environmental factors limiting the sustainable development of agriculture and forestry worldwide ${ }^{1}$. Salinization impairs the productive potential of soil, destroys the habitat of plants, reduces the diversity of communities, and disrupts the ecological chain, which leads to the degradation or loss of ecosystem functions. According to recent statistics, the total area of salinealkali land globally has reached 954 million hectares, with an annual expansion rate of $10 \% 2,3$. Especially at risk are arid and semi-arid areas, where climate conditions characterized by little precipitation and strong evaporation further promote the accumulation of salt in the soil surface. Therefore, it is imperative that researchers to cultivate new varieties of salt-tolerant plants and used more salt-tolerant plants in regional cultivation.

To cope with the ion toxicity and osmotic stress caused by salt stress, plants have evolved a suite of adaptive mechanisms to minimize such damage to cells and tissues ${ }^{4}$. These mainly consist of morphological adaptations ${ }^{5}$, regulation of osmotic substances ${ }^{6}$, defensive functioning of the antioxidant enzyme system ${ }^{7}$, changes in the photorespiration pathway ${ }^{8}$, and ion zone isolation in cells ${ }^{9}$. In addition, some salt-secreting plants can form salt glands and use them or vesicles to secrete excess salt out of the body to avoid a large accumulation of salt ions ${ }^{10}$. In recent years, with rapid advances in proteomics technology, the proteomics approach has provided a powerful shortcut to predict the response of plants to salt stress conditions. Using proteomics technology to reveal differences in protein expression of plants under salt stress is now a research hotspot in the post-genomic era. Previous studies have analyzed the protein composition and change law of cell and subcellular structures in different tissues and organs of salt-stressed plants, such as in Lobular ${ }^{11}$, okra $^{12}$, rice ${ }^{13}$, alfalfa ${ }^{14}$, and licorice ${ }^{15}$, thereby uncovering many salt-reactive proteins conferring salt stress-resistance traits. These include aquaporins, ribosomal protein, heat shock proteins protein kinases, ornithine decarboxylase, ascorbate peroxidase as well as some transcription factors, with another work showing that proteins related to alkaloid synthesis could play a major role in the production of plant secondary metabolites ${ }^{16}$.

Reaumuria soongorica is a typical perennial salt-yielding halophytic shrub, which shows strong adaptability to saline and desert soils, and is a representative dominant species in salt-alkali desert areas of grassland ecosystems. This species plays a crucial role in stabilizing shifting sands, thereby helping to prevent soil erosion and desertification ${ }^{17}$. Further, the $R$. soongorica community provides a good pasture in desert areas, with excellent soil improvement effects. Therefore, this species offers an ideal material for studying and analyzing the physiological responses and molecular regulation mechanism underpinning salt tolerance. To date, studies on salt tolerance of $R$. soongorica have mainly focused on physiological and biochemical indexes, such as ion absorption, seed germination, and antioxidant capacity of callus ${ }^{17-19}$, with no reports yet on the effects of salt stress on the proteomics of $R$. soongorica. In this study, $\mathrm{NaCl}$ was used to impose a salt stress treatment, and a soil salt simulation experiment was conducted to measure the physiological indexes of $R$. soongorica seedlings. Meanwhile, label-free technology was used to study the effects of salt stress on the types and variation laws of differentially expressed proteins in $R$. soongorica seedlings, with the aim of mining those proteins related to salt stress. Clarifying the related metabolic pathways involved in the salt tolerance process of $R$. soongorica can provides important clues for further elucidating the physiological and molecular response mechanisms of $R$. soongorica plants to salt stress conditions, this will provide a more effective scientific basis for breeding enhanced salt tolerant traits in $R$. soongorica. 


\section{Results}

Effects of $\mathrm{NaCl}$ concentrations on growth indicators of R. soongorica seedlings. As shown in Table 1, when compared with control A (i.e., 0 $\mathrm{mM} \mathrm{NaCl}$ ), both the fresh weight and root/shoot ratio of $R$. soongorica in group B (i.e., $200 \mathrm{mM} \mathrm{NaCl}$ ) were significantly higher. However, both fresh weight and root/shoot ratio gradually decreased in group $C$ (i.e., $500 \mathrm{mM} \mathrm{NaCl}$ ). When the $\mathrm{NaCl}$ concentration reached that of group $\mathrm{C}$ (i.e., $500 \mathrm{mM} \mathrm{NaCl}$ ), the growth of $R$. soongorica was significantly inhibited. The fresh weight of above ground and root tissues was respectively $43.82 \%$ and $50.99 \%$ that of the control, and these differences were significant $(P<0.05)$. Under the $\mathrm{NaCl}$ treatment with the $\mathrm{B}$ concentration, the water content of the above ground and root tissues, and the total leaf area of leaves, exceeded that of the control. However, when the $\mathrm{NaCl}$ concentration was $\mathrm{C}$, the water content of above ground and root tissues were significantly lower than those of the control.

Table 1

Effect of different $\mathrm{NaCl}$ concentration treatments on fresh weight, ratio of root, water content and total leaves area of $R$. soongorica plants

\begin{tabular}{|c|c|c|c|c|c|c|c|c|}
\hline \multirow{2}{*}{$\begin{array}{l}\mathrm{NaCl} \\
\text { concentration } \\
\left(\mathrm{mM} \cdot \mathrm{L}^{-1}\right)\end{array}$} & \multicolumn{2}{|c|}{ Fresh weight /mg } & \multicolumn{2}{|c|}{$\begin{array}{l}\text { Fresh weight } \\
\text { percentage /\% }\end{array}$} & \multirow{2}{*}{$\begin{array}{l}\text { Dry weight } \\
\text { /\% } \\
\begin{array}{l}\text { Root-shoot } \\
\text { ratio }\end{array}\end{array}$} & \multicolumn{2}{|c|}{ water content of plant /\% } & \multirow{2}{*}{$\begin{array}{l}\text { Total } \\
\text { leaves } \\
\text { area } \\
\text { of } \\
\text { plant } \\
/ \mathrm{cm}^{2}\end{array}$} \\
\hline & Overground & Root & Overground & Root & & Overground & Root & \\
\hline$A$ & $331.67 \pm 21.08 b$ & $134.67 \pm 6.81 b$ & 100.00 & 100.00 & $\begin{array}{l}0.49 \\
\pm 0.06 b\end{array}$ & $75.20 \pm 3.58 \mathrm{ab}$ & $64.47 \pm 2.48 a$ & $\begin{array}{l}9.66 \\
\pm 0.21 b\end{array}$ \\
\hline B & $392.00 \pm 23.52 a$ & $154.67 \pm 11.24 a$ & 118.19 & 114.85 & $\begin{array}{l}0.60 \\
\pm 0.03 a\end{array}$ & $79.68 \pm 2.10 a$ & $69.12 \pm 2.05 a$ & $\begin{array}{l}10.75 \\
\pm 0.69 a\end{array}$ \\
\hline C & $145.33 \pm 13.50 \mathrm{c}$ & $68.67 \pm 7.51 c$ & 43.82 & 50.99 & $0.41 \pm 0.03 c$ & $71.90 \pm 3.08 b$ & $53.27 \pm 2.07 b$ & $\begin{array}{l}5.55 \\
\pm 0.51 \mathrm{c}\end{array}$ \\
\hline
\end{tabular}

Notes: Different lowercase letters meant significant difference of the growth indexes among different $\mathrm{NaCl}$ concentration at $\mathrm{P}<0.05$ level, The same as below.

Effects of $\mathrm{NaCl}$ concentrations on relative conductivity and proline content of R. soongorica leaves. Under salt stress, figure 1-I shows the responsive changes in the relative conductivity and proline content of $R$. soongorica leaves. The relative conductivity decreased at first and then increased with an increasing $\mathrm{NaCl}$ stress concentration, and the differences were statistically significant. Meanwhile, leaf proline content also increased significantly (Fig. 1-II). These results indicated that $R$. soongorica could adapt to a salt stress environment by adjusting its leaf-level proline content. Under low salt stress, cell membrane system of $R$. soongorica leaves was not damaged by stress, and its cell membrane had strong stability and could adequately adapt to a certain salt environment.

Number of differentially expressed proteins (DEPs). Compared with group A, 47 DEPs were obtained from group B, of which 36 proteins were up-regulated and 11 proteins were down-regulated. Compared with group A, 177 DEPs were obtained from group C, with 126 of them up-regulated and the other 51 proteins down-regulated. Compared with group B, 136 DEPs were obtained from group C: 67 and 69 that were up- and down-regulated, respectively (Fig. 2-I). The identified proteins with significantly different expressions were statistically analyzed, and a certain number of proteins were found common among the three groups, as depicted in Figure 2-II. Evidently, different proteins appeared in the three groups, and there were 12, 83, and 65 specific proteins in the A vs. B, A vs. C, and B vs. C comparison groups, respectively. In both A vs. B and A vs. C groups, 31 differential protein sites were found. Among these, 27 differential protein sites were upregulated and 4 were down-regulated. In the A vs. B and B vs. C groups, there were 8 differential protein sites, 3 up-regulated and 1 downregulated, the other four DEPs showed opposite expression patterns in the two comparison groups. There were 67 differential protein sites in both $A$ vs. $C$ and $B$ vs. $C$ groups: 37 were up-regulated and 30 down-regulated. These results indicated significant differences in protein expression occurred between low salt (B) and high salt (C) conditions in $R$. soongorica seedlings. Notably, 83 proteins were only expressed in $A$ vs. $C$ under high salt stress, and the number was significantly higher than that of other comparison groups.

This may point to the self-protection of plants under high salt stress by initiating greater levels of gene expression.

Hierarchical clustering analysis for DEPs under salt stress. As seen in Figure 3, Each column in the figure represents a sample, and each row represents a protein; color represents the relative expression level of a given protein in the group of samples. On the left is the tree of protein clustering: the closer the branches of two proteins are, the closer their expression levels are, namely, the closer the trends in their variation. By analyzing the up-regulation and down-regulation of different proteins in different sample groups, we can tell that the similarity between the three repeated samples in each group is very high, which would support screening the DEPs accordingly. 
Functional classification of DEPs according to the Clusters of Orthologous Groups (COGs) under salt stress. Figure 4 shows that under salt stress response, DEPs are involved in different biological processes. These included RNA processing and modification, chromatin structure and dynamics, energy production and conversion, amino acid transport, nucleotide transport, and metabolism, among others. There were 29 differential proteins in the A vs. B comparison group that could be annotated and functionally classified by the COG database. These differential proteins were mainly involved in translation, ribosomal structure and biogenesis, function unknown, post-translational modification, protein turnover, and chaperones biological process, of which 21 were up-regulated and 8 were down-regulated. In the A vs. C comparison group, 112 differential proteins were annotated and functionally classified by COG database, these chiefly involved in translation, ribosomal structure and biogenesis, unction unknown, general function prediction only, biological process of energy production and conversion, of which 78 and 34 respectively were up- and down-regulated. There were 86 differential proteins found in the B vs. C comparison group that could be annotated and functionally classified by the COG database. They were mostly involved in translation, ribosomal structure and biogenesis, general function prediction only, post-translational modification, protein turnover, and chaperones biological process with 35 up-regulated and 51 species down-regulated.

Gene Ontology (GO) enrichment analysis for DEPs under salt stress. After their GO annotation, differential proteins were classified according to the functional categories of molecular function (MF),cell component (CC),and biological process (BP).Major biological functions performed bythe DEPS could be determined by a GO significance analysis.In the A vs. B control group analysis, $276 \mathrm{GO}$ items were obtained $(\mathrm{P}<0.05)$,consisting of 194BPitems,31CC items, and 51MF items, with 14 differential proteinsannotated by GO.These DEPs were mainly enriched in translation, response to external stimulus, intracellular structure, ribosome and structural constituent of ribosome, and metabolic process, etc.In the A vs. C control group analysis, $495 \mathrm{GO}$ items were obtained $(\mathrm{P}<0.05)$, namely $274 \mathrm{BP}$ items, 88CC items,and 133MF items, with 82 differential proteinsannotated by GO.These DEPs were mainly enriched in translation, biosynthetic process,ribosome, membrane, structural constituent ofribosome, oxidoreductase activity, and in other ways.In the B vs. C control group analysis, $390 \mathrm{GO}$ items were obtained $(\mathrm{P}<0.05)$,comprising 213BP items, 78CC items, and 99MF items, with 50 differential proteinsannotated by GO.These DEPs were mainly enriched in translation, photosynthesis, cytoplasm, small ribosomal subunit, structural constituent of ribosome, and RNAbinding, etc.(Fig. 5).

KEGG pathway enrichment analysis of DEPs. In face of salt stress, protein functioning depends on the synergistic action of multiple proteins, resulting in significant changes in terms of abundance.

Pathway analysis can provide a more comprehensive and systematic understanding of the biological process each protein is relevant to, and thus point out the metabolic network of salt stress. In order to further understand the biological functions of the uncovered DEPs, their KEGG enrichment analysis was performed. These results showed that (Fig. 6) in the A vs. B comparison group, differential proteins were significantly enriched $(P<0.05)$ to six metabolic pathways (sesquiterpenoid and triterpenoid biosynthesis, glucosinolate biosynthesis, plant-pathogen interaction, ribosome, etc.). The differential proteins of A vs. C comparison group were significantly enriched to 16 metabolic pathways (linoleic acid metabolism, C5-dibasic acid metabolism, porphyrin and chlorophyll metabolism, etc.). Finally, the differential proteins in the B vs. C comparison group were significantly enriched to 13 metabolic pathways (glucosinolate biosynthesis, nitrogen metabolism, SNARE interactions in vesicular transport, etc.).

Identification of protein-protein interaction (PPI) networks among DEPs. To investigate the biological function and regulation of DEPs in $R$. soongorica leaves under salt stress, and to uncover those key proteins related to salt tolerance. For this, a composite score of PPIs (protein interactions) greater than 0.4 was used to determine the interaction network. As Figure 7 shows, five histone interactions were identified in the A vs. B comparison group, and a total of 17 DEPs were involved in the protein interaction network of seedlings under salt stress. The RPS23B (40S ribosomal protein S23-2) and RACK1C (receptor for activated C kinase 1C) had7 and 6 node connections, respectively. The node connections of $A T 5 G 18380$ (40S ribosomal protein S16-3), RPL2-A (50S ribosomal protein L2) and EMB3010 (40S ribosomal protein S6-2) numbered 5 in each case. For P5CR (pyrroline-5-carboxylate reductase), NUDT3 (nudix hydrolase 3), and RPL12-A (60S ribosomal protein L12), each had 3 node connections. In the A vs. C comparison group, 87 DEPs were involved in the protein interaction network under salt stress, and 18 of them had more than 10 node connections, with the most node lines obtained for RPS13 (30S ribosomal protein $\mathrm{S} 13,21$ ), RPS10 (30S ribosomal protein S10, 21), RPL27 (50S ribosomal protein L27, 17), PPOX2 (protoporphyrinogen oxidase 2, 17), RPL29 (50S ribosomal protein L29, 14), and RPL2-A (50S ribosomal protein L2, 14), etc. In the B vs. C comparison group, 61 DEPs were involved in the protein interaction network under salt stress; 14 of them had more than 10 node connections, with the most node lines found for RPS13 (30S ribosomal protein S13, 20), CFBP1 (fructose-1,6-bisphosphatase 1, 18), RPS10 (30S ribosomal protein S10, 17), $R P L 27$ (50S ribosomal protein $\mathrm{L} 27,15), R P S 11 C$ (40S ribosomal protein S11-3, 14), and RPL5 (50S ribosomal protein L5, 13), etc.

Screening of key DEPs in leaves of R. soongorica seedlings under salt stress. Based on the COG database, 29, 112, and 86 DEPs in A vs. B, A vs. C, and B vs. C comparison groups could be annotated and functionally classified. Combined with the differential protein interaction 
regulatory network, protein points with a node connection number $>1$ were selected and repeated proteins in each comparison group were integrated to further screen out the 72 DEPs. The abundance of 34 DEPs increased and 38 DEPs decreased under the salt stress treatments. The most varied proteins were involved in translation, ribosomal structure and biogenesis, amounting to 20 of them, of which 17 belonged to the ribosomal protein family $(R P)$. Six ribosomal proteins ( $R P L 2-A, R P L 12 A, R P S 23 B, R P S 6 B, R P L 30 A$ and $R P S 16 C)$ were up-regulated, while the expression levels of another 11(RPL5, RPS13, RPS10, RPS2D, RPS11C, RPS20B, RPL21A, RPL27, RPS9, RPL29, $R P L 7 A A$ ) were down-regulated under the $\mathrm{NaCl}$ stress. These results showed that $R$. soongorica seedlings could tolerate stress by synthesizing and degrading proteins in response to salt stress conditions. Furthermore, some proteins (GUN4, MRL 1) with pronounced expression differences but not any reported functions were found. These will be investigated in planned future work. The score of the protein was calculated by search software Mascot. If the score was more than 60 , the protein was considered reliable. Finally, four categories of concern were determined and their related DEPs artificially grouped: those proteins related to plant energy and metabolism, those proteins associated with photosynthesis, those proteins related to plant defense and stress resistance, and those participating in protein synthesis, processing, and degradation (Table 2). 
Table 2

The key DEPs were significantly expressed under salt stress

\begin{tabular}{|c|c|c|c|c|c|c|c|}
\hline $\begin{array}{l}\text { Accession } \\
\text { number }\end{array}$ & $\begin{array}{l}\text { Gene } \\
\text { name }\end{array}$ & $\begin{array}{l}\text { Fold } \\
\text { Change }\end{array}$ & $P$ value & $\begin{array}{l}\text { Up/ } \\
\text { down }\end{array}$ & $\begin{array}{l}\text { Comparison } \\
\text { group }\end{array}$ & $\begin{array}{l}\text { Protein } \\
\text { score }\end{array}$ & Protein name \\
\hline
\end{tabular}

Proteins related to plant energy and metabolism

\begin{tabular}{|c|c|c|c|c|c|c|c|}
\hline \multirow[t]{2}{*}{023654} & \multirow[t]{2}{*}{ VHA-A } & 1.513 & 0.006 & up & A vs $\mathrm{C}$ & 78.45 & \multirow[t]{2}{*}{ V-type proton ATPase catalytic subunit A } \\
\hline & & 1.692 & 0.002 & up & B vs C & 78.45 & \\
\hline \multirow[t]{2}{*}{ P20115 } & \multirow[t]{2}{*}{ CSY4 } & 2.348 & 0.019 & up & $A$ vs $B$ & 89.41 & \multirow[t]{2}{*}{ Citrate synthase 4 , mitochondrial } \\
\hline & & 3.893 & $2.563^{\star} 10^{-4}$ & up & A vs C & 89.41 & \\
\hline Q39258 & VHA-E1 & 1.690 & 0.029 & up & A vs $C$ & 73.58 & V-type proton ATPase subunit E1 \\
\hline Q9SU58 & AHA4 & 1.538 & $1.862 * 10^{-4}$ & up & A vs $\mathrm{C}$ & 134.93 & ATPase 4, plasma membrane-type \\
\hline \multirow[t]{2}{*}{ Q9T074 } & \multirow[t]{2}{*}{ PCK1 } & 1.746 & $8.648 * 10^{-4}$ & up & A vs C & 99.35 & \multirow[t]{2}{*}{ Phosphoenolpyruvate carboxykinase (ATP) 1} \\
\hline & & 1.868 & 0.002 & up & $B$ vs $C$ & 99.35 & \\
\hline
\end{tabular}

Proteins associated with photosynthesis

\begin{tabular}{|c|c|c|c|c|c|c|c|}
\hline \multirow[t]{2}{*}{ P10896 } & \multirow[t]{2}{*}{ RCA } & 0.571 & 0.001 & down & $A$ vs $C$ & 61.72 & \multirow{2}{*}{$\begin{array}{l}\text { Ribulose bisphosphate carboxylase } \\
\text { /oxygenase activase, chloroplastic }\end{array}$} \\
\hline & & 0.583 & 0.001 & down & $B$ vs $C$ & 61.72 & \\
\hline Q9SHE8 & PSAF & 0.562 & 0.024 & down & $B$ vs $C$ & 76.16 & $\begin{array}{l}\text { Photosystem I reaction center subunit III, } \\
\text { chloroplastic }\end{array}$ \\
\hline \multirow[t]{2}{*}{ P49107 } & \multirow[t]{2}{*}{ PSAN } & 0.590 & 0.004 & down & A vs $C$ & 65.55 & \multirow{2}{*}{$\begin{array}{l}\text { Photosystem I reaction center subunit N, } \\
\text { chloroplastic }\end{array}$} \\
\hline & & 0.546 & 0.012 & down & $B$ vs $C$ & 65.55 & \\
\hline \multirow[t]{2}{*}{ Q9LR64 } & \multirow[t]{2}{*}{ PSB27-1 } & 0.614 & 0.001 & down & $A$ vs $C$ & 85.30 & \multirow{2}{*}{$\begin{array}{l}\text { Photosystem II repair protein PSB27-H1, } \\
\text { chloroplastic }\end{array}$} \\
\hline & & 0.650 & 0.005 & down & $B$ vs $C$ & 85.30 & \\
\hline
\end{tabular}

Proteins related to plant defense and stress resistance

\begin{tabular}{|c|c|c|c|c|c|c|c|}
\hline \multirow[t]{2}{*}{ P54904 } & \multirow[t]{2}{*}{ P5CR } & 1.515 & 0.006 & up & A vs B & 63.85 & \multirow[t]{2}{*}{ Pyrroline-5-carboxylate reductase } \\
\hline & & 3.112 & 0.003 & up & A vs $C$ & 63.85 & \\
\hline 004921 & FC2 & 1.675 & 0.028 & up & A vs $C$ & 95.80 & Ferrochelatase-2, chloroplastic \\
\hline Q9SF29 & SYP71 & 1.619 & 0.015 & up & $B$ vs $C$ & 88.56 & Syntaxin-71 \\
\hline Q9SRV7 & SYP131 & 1.673 & 0.016 & up & B vs C & 74.66 & Putative syntaxin-131 \\
\hline
\end{tabular}

Protein synthesis, processing and degradation

\begin{tabular}{|c|c|c|c|c|c|c|c|}
\hline \multirow[t]{2}{*}{ P56791 } & \multirow[t]{2}{*}{ rpl2-A } & 2.096 & 0.011 & up & $A$ vs $B$ & 60.50 & \multirow[t]{2}{*}{50 S ribosomal protein L2, chloroplastic } \\
\hline & & 2.892 & 0.052 & up & A vs $C$ & 60.50 & \\
\hline \multirow[t]{2}{*}{ P36210 } & \multirow[t]{2}{*}{ RPL12A } & 2.832 & 0.009 & up & $A$ vs $B$ & 71.98 & \multirow[t]{2}{*}{50 S ribosomal protein L12-1, chloroplastic } \\
\hline & & 2.543 & 0.013 & up & A vs $C$ & 71.98 & \\
\hline P51430 & RPS6B & 1.909 & 0.038 & up & $A$ vs $B$ & 61.36 & 40S ribosomal protein S6-2 \\
\hline P49692 & RPL7AA & 0.651 & 0.032 & down & A vs $C$ & 63.75 & $60 S$ ribosomal protein L7a-1 \\
\hline Q9SCM3 & RPS2D & 0.579 & $7.254 * 10^{-5}$ & down & A vs $\mathrm{C}$ & 60.24 & $40 S$ ribosomal protein S2-4 \\
\hline \multirow[t]{2}{*}{ Q9LK61 } & \multirow[t]{2}{*}{ RPS10 } & 0.659 & 0.021 & down & A vs C & 75.71 & \multirow[t]{2}{*}{ 30S ribosomal protein S10, chloroplastic } \\
\hline & & 0.616 & 0.002 & down & B vs C & 75.71 & \\
\hline Q9XJ27 & RPS9 & 0.642 & $2.142 * 10^{-5}$ & down & A vs $C$ & 73.93 & 30 S ribosomal protein S9, chloroplastic \\
\hline
\end{tabular}




\begin{tabular}{|llllllll|}
\hline $\begin{array}{l}\text { Accession } \\
\text { number }\end{array}$ & $\begin{array}{l}\text { Gene } \\
\text { name }\end{array}$ & $\begin{array}{l}\text { Fold } \\
\text { Change }\end{array}$ & P value & $\begin{array}{l}\text { Up/ } \\
\text { down }\end{array}$ & $\begin{array}{l}\text { Comparison } \\
\text { group }\end{array}$ & $\begin{array}{l}\text { Protein } \\
\text { score }\end{array}$ & Protein name \\
\hline A2RVR7 & At2g47020 & 1.738 & $6.313^{*} 10^{-4}$ & up & A vs C & 95.71 & Peptide chain release factor 1, mitochondrial \\
\hline
\end{tabular}

\section{Discussion}

\section{Effect of $\mathrm{NaCl}$ concentration on growth indicators and leaf physiological indexes of $\mathrm{R}$. soongorica seedlings}

Salinity is undoubtedly a worsening worldwide problem, being a major abiotic stress affecting the growth, development, and productivity of plants ${ }^{20}$. Nevertheless, there are differences in the mechanisms of tolerance to salt stress among different species of plants. Osmotic stress is a direct response of plants to salt stress, and plants can mitigate their incurred damage by regulating intracellular regulatory substances ${ }^{21,22}$. In addition, the generation and transport of biomass is also an important factor in assessing the degree of salt stress in plants $^{23}$. Studies have shown that salt stress reduces plant biomass synthesis, and that plant leaves are capable of responding to salt stress via the rapid accumulation of proline ${ }^{24-26}$. In our experiment, under the stress condition of low salt B (200 mM NaCl), the fresh weight and root/shoot ratio of $R$. soongorica seedlings increased, and low salt had a significant promotional effect on their growth. Yet when the $\mathrm{NaCl}$ concentration reached $\mathrm{C}(500 \mathrm{mM} \mathrm{NaCl})$, the seedlings' fresh weight and root-shoot ratio decreased, and their growth was inhibited significantly. These results, which are consistent with those of Nasim et al. for Butterfly pea could be explained by the high salt tolerance of $R$. soongorica in the imposed salinity range; specifically, by it effectively relying on $\mathrm{Na}^{+}$and $\mathrm{Cl}^{-}$accumulation to regulate cell permeability and maintain expansion, and by effective $\mathrm{K}^{+}$homeostasis to maintain stomatal functioning in leaves. The inhibition of seedling growth under high salt conditions is likely due to the limited ability to isolate $\mathrm{Na}^{+}$and $\mathrm{Cl}^{-}$in vacuoles ${ }^{28}$. The proline content in $R$. soongorica leaves increased significantly with a greater salt concentration, a result consistent with findings of previous studies, possibly because the proline synthesis gene was activated or the expression of proline degradation gene was inhibited under salt stress ${ }^{25}$.

\section{DEPs in leaves of R. soongorica under salt stress}

\section{Proteins related to plant energy and metabolism}

It is necessary for plant growth and development to produce catabolic energy in the face of salinity. Glycolysis and the tricarboxylic acid (TCA) cycle are the major pathways for energy production ${ }^{29}$, and $C S$ is a key enzyme of the TCA cycle ${ }^{30}$. Up-regulation of $C S$ expression can improve the tolerance of maize to salt stress ${ }^{31}$. We found that the expression of the CS family protein (CSY4) was up-regulated by 2.35 and 3.89 times under low salt (A vs. B) and high salt (A vs. C) stress, respectively. Up-regulation of the TCA pathway would contribute to the production of $R$. soongorica catabolic energy to support its seedling growth under salt stress conditions. $V$-atpase plays a key role in activating the secondary active transport of plants and is an indispensable enzyme in plants, especially for coping with abiotic stresses ${ }^{32}$. For example, overexpression of vacuolar $V$-ATpase $\mathrm{C}$ subunit protein gene was shown to augment the salt tolerance ability of tobacco ${ }^{33}$. We found two isoforms (VHA-A, VHA-E1) of V-ATPase in leaves of $R$. soongorica. Both were up-regulated under imposed salt stress, while $A H A 4$ was up-regulated in the plasma membrane. This may be because the up-regulated expression levels of VHA-A, VHA-E1, and $A H A 4$ are associated with the uptake and transport of $\mathrm{Ca}^{+}$and $\mathrm{K}^{+}$, which are involved in the regulation of protein homeostasis under salt stress. Phosphoenolpyruvate carboxykinase ( $P C K 1)$ functions as a catalytic enzyme, converting oxaloacetate to regulate protein homeostasis under salt stress phosphoenolpyruvate, an intermediate product in glycolysis ${ }^{34}$. The increased expression of this protein in $R$. soongorica leaves under salt stress may be linked this plant's ability to resist salt stress.

Proteins associated with photosynthesis

Photosynthesis is the most important process in plant metabolism ${ }^{35}$. Rubisco is a key enzyme in the dark reaction of photosynthesis and plays a central role in carbon fixation ${ }^{36}$. Under salt stress, rubisco protein expression in Prunus mume leaves was down-regulated ${ }^{37}$, but expression of Haloxylon salicornicum was up-regulated in the same leaves ${ }^{38}$. We found that rubisco (RCA) expression was down-regulated in the $A$ vs. $C$ and $B$ vs. $C$ comparison groups, suggesting that down-regulated rubisco expression may lead to reduced light energy utilization in R. soongorica leaves while under salt stress. In plants, PSAN is the subunit that mediates LHCll energy transfer to the photosystem I (PSI) core, it figures prominently in fostering efficient electron transport from plastocyanin to P700. In eukaryotic photosynthetic organisms, the PSI subunit PsaF is involved in the docking of the electron-donor proteins plastocyanin and cytochrome $\mathrm{c6}^{39}$; however, salt-alkali stress can significantly reduce the binding stability between the subunits of $\mathrm{PSI}{ }^{40}$. In this the present study, the expression levels of both PSAN and PsaF in R. soongorica were decreased under salt stress, perhaps because salt stress inhibits the electron transfer mechanism in its leaves. Photosystem II (PSII) is prone to photoinduced damage; hence, it is continuously repaired to 
maintain its function. The Psb27 protein interacts with the CP43 subunit of PSII and participates in this repair of PSII, and in Arabidopsis two Psb27-like proteins (Psb27-H1 and Psb27-H2) were found involved in PSII repair ${ }^{41}$. Our study found that the Psb27-1 protein was down-regulated by 0.61 and 0.65 times in the $A$ vs. $C$ and $B$ vs. C comparison groups, respectively, which could be explained by damage to both the donor side and recipient side of PSII, and severe photoinhibition of both PSII and PSI. These results suggest that these four photosynthesis-related proteins may play important roles in the leaf response to salt stress.

Proteins related to plant defense and stress resistance

Pyrroline-5-carboxylic acid reductase (P5CR) is a terminal enzyme that functions critially in proline biosynthesis ${ }^{42}$. To improve their salt tolerance, the leaves of Sorghum bicolor ${ }^{43}$ and sweet potato $L .{ }^{44}$ can accumulate large amounts of proline via overexpression of the $P 5 C R$ protein under salt stress. In our study, the P5CR protein was up-regulated by 1.51 and 3.11 times under low and high salt stress, respectively, which further explains why the proline content increased under salt stress as shown in Figure 1-II. It has been suggested that proline could induce the expression of responsive genes in response to physiological stress caused by to much salinity. Previous reports have revealed the salt stress induced the expression of FC2 in Arabidopsis leaves ${ }^{45}$. Likewise, in $R$. soongorica, high salt stress caused the FC2 to increase by 1.68 times. This shows that under high salt conditions, FC2 protein expression can effectively control the transport and distribution of metal in the cell, enabling each leaf cell to reach a steady state equilibrium, which showed entails a certain tolerance to salt stress. SNARE proteins drive vesicle transport and transport membrane functioning, taking cargo to target sites within and on the cell surface, thereby contributing to cell homeostasis, morphogenesis and pathogen defense ${ }^{46}$. SYP proteins are a family of QC-SNARE proteins unique to plants. In Arabidopsis, SYP121 interacts with KAT1 and KC1 (K channels) to regulate $\mathrm{K}^{+}$currents in the plasma membrane ${ }^{47}$. The up-regulated expression of SISYP51.2 protein is known to enhance tomato plant's tolerance of salt stress ${ }^{48}$. In our study, both SYP71 and SYP131 proteins were up-regulated under high salinity (A vs. C), suggesting these proteins may similarly regulate the activity of metal ion channels and thus improve $R$. soongorica's tolerance of salt stress.

\section{Protein synthesis, processing, and degradation}

Ribosome synthesis can trigger the nucleolar stress response and activate $\mathrm{p} 53$, thus maintaining the stability of the intracellular environment ${ }^{49}$. The ribosome consists of two parts, the case ribosomal protein $(R P)$ and ribosomal RNA. The $R P$ not only maintains the configuration of RNA, but also participates in the synthesis, transport, and localization of proteins ${ }^{50}$. Salinity reduced the ribosomal protein expression abundance in creeping bentgrass ${ }^{51}$. Li et al. ${ }^{52}$ found that for upland cotton under salt stress, the abundance of two ribosomal proteins decreased whereas that of two ribosomal proteins increased. Our data showed the abundance of three ribosomal proteins ( $R P L 2-$ $A, R P L 12 A$, and RPS6B) increasing significantly under low salt stress, which suggests the overall protein synthesis level of $R$. soongorica seedlings increased under conditions of low salt stress and promoted this plant's growth. Under high salt stress, the abundance of two ribosomal proteins ( $R P L 2-A$ and $R P L 12 A)$ increased significantly, and the abundance of four ribosomal proteins (RPS10, RPS2D, RPS9 and RPL7AA) decreased significantly. Yet, at the same time, the expression of a peptide chain releasing factor (At2g47020) was significantly up-regulated, indicating that the overall protein synthesis level of $R$. soongorica seedlings is decreased under conditions of high salt stress. The differential regulation of different ribosomal proteins in the translation mechanism suggests that $R$. soongorica seedlings cope with high salt stress by balancing ribosomal proteins' synthesis and degradation.

\section{Materials And Methods}

Plant materials. Seeds of $R$. soongorica were collected from Laohukou, Wuwei, in Gansu Province, China $\left(102^{\circ} 58^{\prime} \mathrm{E}, 38^{\circ} 44^{\prime} \mathrm{N}\right.$; elevation $1315-1375 \mathrm{~m}$ ), in late October, 2019. The average annual temperature, rainfall, and evaporation of this sampling area is $7.5^{\circ} \mathrm{C}, 110 \mathrm{~mm}$, and 2,646 mm, respectively. The seeds (voucher numbers: 063-2) were identified by Dr. X. Liu, at the Institute of Gansu Minqin National Studies Station for Desert Steppe Ecosystems (MSDSE); seed samples were deposited at the Herbarium of Scientific Research Experimental Station of the Longqu Seed Orchard, Gansu Province Academy of Qilian Water Resource Conservation Forests Research, in Zhangye. These seeds were put inside a seed storage cabinet (CZ-250FC, Top Yunong, Zhejiang, China) until their later use. Plant materials were collected in strict accordance with the Technical Regulations for the seed Collection of Rare and Endangered wild Plants of the People's Republic of China (LYT2590 - 2016).

Plant growth and salt treatments. The experimental research on plants were carried out in accordance with technical regulations for cultivation of tree seedings (DB11T476-2007), Forestry Industry Standard (LY/T 1898-2010) and soil and Water conservation test Standard (SD 239-87) issued by the Ministry of Water Resources of the People's Republic of China. The experiments were carried out in the No. 4 experimental shed of the Scientific Research Experimental Station of Longqu Seed Orchard, in Zhangye, Gansu Province, China (100 ${ }^{\circ} 22{ }^{\prime} E$, $38^{\circ} 78^{\prime} \mathrm{N}$; elevation 1591-1681 m). In April 2020, uniform full-sized seeds were selected and disinfected for 8 min with $1 \%$ NaClO and 
rinsed for six times with ultra-pure water. Cleaned seeds were then sown in a plug tray $(8.5 \mathrm{~cm}$ height $\times 4.5 \mathrm{~cm}$ diameter, with drainage holes at the bottom) filled with vegetative soil, quartz sand, and vermiculite (3:1:1), and sprinkler irrigated with underground water. They were cultivated in the greenhouse at a temperature of $25 \pm 1^{\circ} \mathrm{C}$ under $50 \%$ humidity with ventilation and natural light. In July 2020 , local farming soil was selected for use in the pot experiments; this soil type is that of irrigated desert soil. Before transplanting, an intelligent soil nutrient analyzer (TPY-6A, Top Yunong, Zhejiang, China) was used to determine the available phosphorus, ammonium nitrogen, salinity, and $\mathrm{pH}$ of the tested soil, which were $26.6 \mathrm{mg} / \mathrm{kg}, 10.0 \mathrm{mg}, 0.2 \%$, and 8.3 , respectively. Next, uniformly germinated seedlings were transferred into plastic pots containing $2.5 \mathrm{~kg}$ of soil (pot dimensions: $23 \mathrm{~cm}$ wide at the top, $13 \mathrm{~cm}$ wide at the bottom, and $14 \mathrm{~cm}$ in height). Intelligent watering control systems were used to maintain the soil water content close to field capacity (i.e., $60 \%$ ). The salt treatments were applied after 1 month of slow seedling. Seedlings were thinned to four plants per pot, with five pots in each group to which 0 (control, A), 200 (low salt, B), or 500 (high salt, C) mM NaCl was supplied, for a total of three treatment groups (15 pots, 60 seedlings in all). To reduce measurement error, each group was tested three times (Table 3 ). According to the experimental design, the corresponding $\mathrm{NaCl}$ solution was prepared with deionized water, and using a syringe it was evenly poured around the root system of $R$. soongorica plants. To avoid osmotic shock in seedlings caused by a salt shock reaction, the target concentration was reached over a 24-hperiod via gradual salt applications. The $\mathrm{NaCl}$ treatment for $24-48 \mathrm{~h}$ was set as the $\mathrm{NaCl}$ treatment at day 0 , and the relevant indexes were measured after 3 days.

Table 3

Experimental treatment

\begin{tabular}{|llll|}
\hline $\begin{array}{l}\text { NaCl concentration } \\
\text { Treatment }\end{array}$ & $\mathbf{0 ~} \mathbf{m M} \cdot \mathrm{L}^{-\mathbf{1}}(\mathrm{A})$ & $\mathbf{2 0 0} \mathbf{m M} \cdot \mathrm{L}^{-\mathbf{1}}(\mathrm{B})$ & $\mathbf{5 0 0 m M} \cdot \mathrm{L}^{-\mathbf{1}}(\mathrm{C})$ \\
\hline group 1 & A1 & B1 & $\mathrm{C} 1$ \\
\hline group 2 & A2 & B2 & $\mathrm{C} 2$ \\
\hline group 3 & A3 & B3 & C3 \\
\hline
\end{tabular}

\section{Morphological and physiological indexes determination Determination of plants' wet weight, dry weight, and ratio of roots to shoots}

The 10 plants from each treatment group were washed with distilled water and dried with absorbent paper. We then counted their main stem, branches, and leaves above the rhizosphere, as aboveground parts. The fresh weight (FW) of the roots and aboveground parts of the plants was obtained and the mean value per plant was calculated. Then they were dried (at $105^{\circ} \mathrm{C}$ in an oven for 30 min, and dried again to constant weight at $80^{\circ} \mathrm{C}$ ) and reweighed. Root/shoot ratio $(\mathrm{R} / \mathrm{T})=$ dry weight of underground part/dry weight of aboveground parts.

\section{Measurement of a leaf's total surface area}

The total surface area of single plant leaf was measured with a Leaf Area Analyzer (LI-3000C, Legol Tech, Beijing, China). The area of two clean plastic sheets was first measured to eliminate error. The $R$. soongorica leaves were removed with scissors and tweezers, and individually placed between the two plastic sheets and passed under the scanning head, to obtain their total surface area.

Determination of leaf relative conductivity and proline Content

The relative conductivity of each sample was measured according to $\mathrm{Hu}^{\prime} \mathrm{s}^{53}$ measurement method, with some modifications. Weigh $0.3 \mathrm{~g}$ $R$. soongorica fresh leaves, rinse surface stains, dry them with absorbent paper, place them in a $50 \mathrm{ml}$ conical bottle, add $20 \mathrm{ml}$ deionized water, place them at room temperature for $3 \mathrm{~h}$, measure the conductivity of the solution with a conductivity meter (DDS-W, Bant instrument, Shanghai, China), record, and then put them into a thermostatic water bath at $100^{\circ} \mathrm{C}$, boil for $15 \mathrm{~min}$, cool, and determine the conductivity of the solution as R2. The relative conductivity (\%) in leaves was calculated as conductivity/the final conductivity $\times 100 \%$. The Proline Content of the $R$. soongorica leaves was determined as described by the method of Sajid ${ }^{54}$.

Analysis and identification methods of differential proteomics in leaves of R. soongorica under salt stress. The differential proteomics analysis and protein identification conducted for leaves of $R$. soongorica followed the described methods of Kumaravel et al. ${ }^{55}$, Holáet et al. ${ }^{56}$, and Kumar et al. ${ }^{57}$, with some modifications introduced. The preparation of proteome libraries and their deep sequencing were both performed by the Naomi Metabolic Technology Corporation (Suzhou, China). 


\section{Protein extraction and quantification}

For this, a given leaf sample was taken from ultra-low temperature refrigerator $\left(-80^{\circ} \mathrm{C}\right)$, ground it into fine powder in liquid nitrogen at low temperature, and put it into an EP tube. Then a $100-\mu \mathrm{L}$ powder subsample was added into a new EP tube, to which $500 \mu \mathrm{L}$ methanol was added, mixed well, the allowed to rest on ice for $10 \mathrm{~min}$, after which it was centrifuged $\left(14000 \times \mathrm{g}, 4^{\circ} \mathrm{C}\right)$ for $5 \mathrm{~min}$ and the ensuing supernatant removed (repeated four times). Finally, the methanol residue in the precipitate was cleaned with $1 \times$ PBS, centrifuged (14 000x $g, 4^{\circ} \mathrm{C}$ ) for $5 \mathrm{~min}$, and the precipitate then collected. To each sample, $500 \mu \mathrm{L}$ of an $8 \mathrm{M}$-urea lysis buffer was added, and this ultrasonicated on ice for 10 min (power: 15\%, ultrasonic $3 \mathrm{~s}$, stop $3 \mathrm{~s}$ ). The protein was quantified by SDS-PAGE electrophoresis.

\section{Trypsin digestion}

According to the quantitative results of the electrophoretic diagram, $200 \mu \mathrm{L}$ of protein lysate was taken from each sample and placed in a centrifugal tube for an enzyme digestion. We added $2 \mu \mathrm{L}$ of $1 \mathrm{M}$ DTT (DL-Dithiothreitol, Promega, Beijing, China) to each tube, mixed it, heated it at $56^{\circ} \mathrm{C}$ for $15 \mathrm{~min}$, and the briefly spun it by centrifuging, after which it was cooled to room temperature. Each sample was divided into four tubes: $50 \mu \mathrm{L}$ per tube, to which $150 \mu \mathrm{L}$ of $50 \mathrm{mM} \mathrm{ABC} \mathrm{(Vectastain} \mathrm{ABC} \mathrm{Kit,} \mathrm{Jinpan,} \mathrm{Shanghai,} \mathrm{China)} \mathrm{was} \mathrm{added} \mathrm{to} \mathrm{attain}$ a $2 \mathrm{M}$-urea concentration. Next, we added $1.5 \mu \mathrm{g}$ trypsin (Putai, Hangzhou, China) to each tube, mixed it with a pipette gun, cut by enzymatic at $37^{\circ} \mathrm{C}$ for $4 \mathrm{~h}$, then added $1.5 \mu \mathrm{g}$ trypsin, cut by enzymatic at $37^{\circ} \mathrm{C}$ overnight. After this enzyme digestion process, $20 \mu \mathrm{L} 10 \%$ FA (Fisher Scientific, A117-50, Fisher, America) was added and centrifuged at $14000 \times g$, from which supernatant was removed for desalting. Finally, one sample was taken from each group, and each analyzed by liquid chromatography-tandem mass spectrometry for 1 h.

\section{Peptide fragment labeling and fractionation}

The labeled peptide was dissolved in a 0.1M TEAB (triethylamine-carbonate) buffer ( $\mathrm{pH}=8.5)$. We took out a tube containing $0.1 \mathrm{mg}$ of the TMT (TMT10 plex ${ }^{\mathrm{TM}}$, Thermo Scientific ${ }^{\mathrm{TM}}$, America) reagent, added $12 \mu \mathrm{L}$ of acetonitrile, vortexed it for $10 \mathrm{~s}$, then placed it at room temperature for $5 \mathrm{~min}$, and the repeated the vortex ( 3 times) to ensure the TMT reagent was fully mixed in. Then $10 \mu \mathrm{L}$ of the peptide (10 $\mu \mathrm{g}$ ) was removed and added to the corresponding TMT reagent, according to labeling information table (Table 4). Different samples were labeled with a different labeling reagent, and these thoroughly mixed by vortexing, and allowed to sit at room temperature for $1 \mathrm{~h}$. After that, the labeling reaction was stopped. A 1- $\mu$ g sample was taken from this mixture and mixed with $150 \mu \mathrm{L}$ of $1 \%$ FA for desalting. The mass spectrometry method was used for detection, for which the labeling efficiency must be higher than $95 \%$ to reach the standard. The remaining mixture samples were stored at $-80^{\circ} \mathrm{C}$ to be separated. The eluent was mixed into two fractions by the strong cation exchange (SCX) method, and then the two fractions were added to different C18 reversed-phase columns. The peptides were eluted by an $80-\mu \mathrm{L} C A N$ (cerium ammonium nitrate, Fisher Scientific, Pittsburgh, America) solution. Finally, the eluted peptides were mixed into six fractions and stored at $-80^{\circ} \mathrm{C}$ for the mass spectrometry detection.

Table 4

Peptide labeling information table

\begin{tabular}{|lllllllll|}
\hline TMT & TMT & TMT & TMT & TMT & TMT & TMT & TMT & TMT \\
126 & $127 \mathrm{~N}$ & $127 \mathrm{C}$ & $128 \mathrm{~N}$ & $128 \mathrm{C}$ & $129 \mathrm{~N}$ & $129 \mathrm{C}$ & $130 \mathrm{~N}$ & $130 \mathrm{C}$ \\
\hline $\mathrm{A} 1$ & A2 & A3 & B1 & B2 & B3 & C1 & C2 & C3 \\
\hline
\end{tabular}

\section{Mass spectrometry analysis}

Orbitrap Fusion Lumos (Thermo Fisher Scientific, USA) mass spectrometer was used for the data collection. The ion source was nano current electrospray ion source (NSI) with a spray voltage of $2200 \mathrm{~V}$ and an ion transport capillary temperature of $320^{\circ} \mathrm{C}$. The mass spectrometry data were collected in the positive ion mode by data-dependent acquisition mode (DDA). Orbitrap was used for full scans at level 1. Secondary mass spectrometry acquisition was performed by fragmentation of parent ions with $38 \%$ high-energy collision dissociation (HCD), and the ensuing fragment ions were detected in Orbitrap.

\section{Qualitative and quantitative analysis of proteins}

After the completion of MS scanning, the total ion flow chromatogram of MS signal was obtained. After the mass spectrum data were inputted into Proteome Discoverer software (PD) (v2.2, Thermo Fisher Scientific), the software first screened the mass spectrum. This mass spectrum data was searched via the Sequest operation program embedded in the PD software. The same software conducted a

Page $10 / 18$ 
qualitative analysis according to the Sequest search results and the spectrum (after the first screening step). By extracting the signal value of TMT reporting ions, the protein quantification value was recalculated, this represented here by its median, where the protein quantification value was the sum of the obtained peptide quantification values.

Statistical and bioinformatics analysis. Microsoft Excel 2016 was used for data processing and analysis, and Origin 8.0 was used for plotting. SPSS 22.0 analysis software was used for analysis of variance and principal component analysis. The functional enrichment database did not provide the enrichment analysis of $R$. soongorica leaves. Therefore, the identified protein sequences were compared with the background libraries of GO and KEGG by blast, respectively. It was determined Arabidopsis as the best species after comparison and the protein information for mutual comparison, and the compared information of arabidopsis proteins are used in the following founction enrichment analysis. In relative quantification, protein expression abundance was set to determine the statistical significance of the difference and accurately identify the DEPs induced by salt stress. When the protein difference multiple was $>1.5$ and its P-value $<0.05$, it was considered an up-regulated protein; when the difference multiple was $<0.66$ and the P-value $<0.05$, the protein was designated as down-regulated. The functions of all identified proteins were determined by searching GO (Gene Ontology) analysis in UniProt database (http://www.uniprot.org), and proteins were classified according to their main functions. we used the string-DB (http://string-db.org/) protein interaction database (selecting Arabidopsis thaliana) to analyze the interaction of compared and differentially expressed proteins.

\section{Conclusion}

As a salt-secreting plant, $R$. soongorica underwent a series of changes in its growth and differentially expressed proteins in its leaves while under controlled salt stress conditions. In terms of its growth indexes, low salt $\left(200 \mathrm{mM} \cdot \mathrm{L}^{-1}\right)$ significantly promoted the vegetative growth (total leaf area, total fresh weight, root shoot ratio) of $R$. soongorica seedlings, while increasing the proline content of their leaves.

Proteomic analysis revealed that energy- and metabolism-related proteins ( P5CR, CSY4) and ribosomal proteins ( $R P L 2-A, R P L 12 A, R P S 6 B)$ were up-regulated under low salt stress. However, the growth of $R$. soongorica seedlings was significantly inhibited under high salinity (500 $\left.\mathrm{mM} \cdot \mathrm{L}^{-1}\right)$. The reason for this may be that high salt decreases the abundance of proteins associated with photosynthesis $(R C A, P S A F$, $P S A N, P S B 27-1)$, ribosomal proteins ( $R P S 10, R P S 2 D, R P S 9, R P L 7 A A)$ yet it increases the abundance of a peptide chain-releasing factor (at2g47020). Meanwhile, $R$. soongorica may respond to a high salt stress environment by up-regulating the expression of genes related to energy and metabolism (VHA-A, VHA-E1, AHA4, CSY4, PCK1), defense and anti-stress related proteins (P5CR, FC2, SYP71, SYP131) and ribosomal proteins (RPL2-A, RPL 12A) in its leaves. These proteins play an important role as a potential target protein conferring the salt tolerance ability of $R$. soongorica. This study lays a foundation for better understanding the molecular regulation mechanism underlying the salt stress response of $R$. soongorica.

\section{Declarations}

\section{Acknowledgments}

The work was supported by the Regular Science and Technology Assistance Programs to Developing Countries (KY202002011), the Central Finance of Forestry Science and Technology Promotion Demonstration Funds of China (2020ZYTG15), the Natural Science Foundation of Gansu Province (20JR5RA035), the Science and Technology Innovation Base and Talents Program of Gansu Province (17JR7WA018), the National Natural Science Foundation of China (32160497). the Physiological Characteristics and Molecular mechanism of Salt Tolerance of Reaumuria reaumuria in Response to salt Stress (GAU-QDFC-2021-10).

\section{Author Contributions Statement}

S.Y. and P.C. conceived and designed the experiments; S.Y. and M.Z. performed the experiments; S.Y. and P.C. analyzed the data; M.Z. and H.L. contributed reagents, materials, and analysis tools; S.Y. wrote and revised the paper. All authors contributed to the research project design and manuscript preparation.

\section{Competing interests}

The authors declare no competing interests.

\section{Ethics approval and consent to participate}

The experimental research and field studies on plants or seeds in this work comply with the IUCN Policy Statement on Research Involving Species at Risk of Extinction and the Convention on the Trade in Endangered Species of Wild Fauna and Flora. 


\section{References}

1. Cuevas J, Daliakopoulos IN, Moral FD, Hueso JJ, Tsanis IK. A Review of Soil-Improving Cropping Systems for Soil Salinization. Agronomy 9, 295, https://doi.org/10.3390/agronomy9060295 (2019).

2. Li WY, Wang C, Shi HH, Wang B, Wang JX, Liu YS, Ma JY, Tian SY, Zhang YW. Genome-wide analysis of ethylene-response factor family in adzuki bean and functional determination of VaERF3 under saline-alkaline stress. Plant Physiology and Biochemistry 147, 215-222, https://doi.org/10.1016/j.plaphy.2019.12.019 (2019).

3. Jamil A, Riaz S, Ashraf M, Foolad MR. Gene Expression Profiling of Plants under Salt Stress, Critical Reviews in Plant Sciences. Critical Reviews in Plant Sciences 30, 435-458, https://doi.org/10.1080/07352689.2011.605739 (2011).

4. Almeida DM, Margarida OM, Saibo NJM. Regulation of $\mathrm{Na}+$ and $\mathrm{K}+$ homeostasis in plants: towards improved salt stress tolerance in crop plants. Genetics and Molecular Biology 40, 326-345, https://doi.org/10.1590/1678-4685-gmb-2016-0106 (2017).

5. Arif $Y$, Singh P, Siddiqui H, Bajguz A, Hayat S. Salinity induced physiological and biochemical changes in plants: An omic approach towards salt stress tolerance. Plant Physiology and Biochemistry 156, 64-77, https://doi.org/10.1016/j.plaphy.2020.08.042 (2020).

6. García-Caparrós P, Llanderal A, Hegarat E, Jiménez-Lao M, Lao MT. Effects of Exogenous Application of Osmotic Adjustment Substances on Growth, Pigment Concentration, and Physiological Parameters of Dracaena sanderiana Sander under Different Levels of Salinity. Agronomy 10, 125, https://doi.org/10.3390/agronomy10010125 (2020).

7. Asrar H, Hussain T, Qasim M, Nielsen BL, Gul B, Khan MA. Salt induced modulations in antioxidative defense system of Desmostachya bipinnata. Plant Physiology and Biochemistry 147, 113-124, https://doi.org/10.1016/j.plaphy.2019.12.012 (2020).

8. Ziotti ABS, Silva BP, Sershen, Lima Neto MC. Photorespiration is crucial for salinity acclimation in castor bean. Environmental and Experimental Botany 167, 103845, https://doi.org/10.1016/j.envexpbot.2019.103845 (2019).

9. Javaid T, Farooq MA, Akhtar J, Saqib ZA, Anwar-ul-Haq M. Silicon nutrition improves growth of salt-stressed wheat by modulating flows and partitioning of $\mathrm{Na}^{+}, \mathrm{Cl}^{-}$and mineral ions. Plant Physiology and Biochemistry 141, 291-299, https://doi.org/10.1016/j.plaphy.2019.06.010 (2019).

10. Kuster VC, Silva LC, Meira RMSA. Anatomical and histochemical evidence of leaf salt glands in Jacquinia armillaris Jacq. (Primulaceae). Flora 262, 151493, https://doi.org/10.1016/j.flora.2019.151493 (2020).

11. Jia T, Wang F, Chang W, Fan X, Sui X, Song F. Proteomics Analysis of E. angustifolia Seedlings Inoculated with Arbuscular Mycorrhizal Fungi under Salt Stress. International Journal of Molecular Sciences 20,788, https://doi.org/10.3390/ijms20030788 (2019).

12. Zhan Y, Wu Q, Chen Y, Tang M, Sun C, Sun J, Yu C. Comparative proteomic analysis of okra (Abelmoschus esculentus L.) seedlings under salt stress. BMC Genomics 20, 381, https://doi.org/10.1186/s12864-019-5737-7 (2019).

13. Hussain S, Zhu C, Bai Z, Huang J, Zhu L, Cao X, Nanda S, Hussain S, Riaz A, Liang Q, Wang L, Li Y, Jin Q, Zhang J. ITRAQ-Based Protein Profiling and Biochemical Analysis of Two Contrasting Rice Genotypes Revealed Their Differential Responses to Salt Stress. International Journal of Molecular Sciences 20, 547, https://doi.org/10.3390/ijms20030547 (2019).

14. Li J, Essemine J, Shang C, Zhang H, Zhu X, Yu J, Chen G, Qu M, Sun D. Combined Proteomics and Metabolism Analysis Unravels Prominent Roles of Antioxidant System in the Prevention of Alfalfa (Medicago sativa L.) against Salt Stress. International Journal of Molecular Sciences 21, 909, https://doi.org/10.3390/ijms21030909 (2021).

15. Wang C, Chen L, Cai Z, Chen C, Liu Z, Liu X, Zou L, Chen J, Tan M, Wei L, Mei Y. Comparative Proteomic Analysis Reveals the Molecular Mechanisms Underlying the Accumulation Difference of Bioactive Constituents in Glycyrrhiza uralensis Fisch under Salt Stress. Journal of agricultural and food chemistry 68, 1480-1493, https://doi.org/10.1021/acs.jafc.9b04887 (2020).

16. Keyvan A, Setsuko K. Crop and medicinal plants proteomics in response to salt stress. Frontiers in Plant Science 4, 8 , https://www.frontiersin.org/article/10.3389/fpls.2013.00008 (2013).

17. Zhang H, Liu X, Yang X, Wu H, Zhu J, Zhang H. miRNA-mRNA Integrated Analysis Reveals Roles for miRNAs in a Typical Halophyte, Reaumuria soongorica, during Seed Germination under Salt Stress. Plants 9, 351, https://doi.org/10.3390/plants9030351 (2020).

18. Zhao Xin, Yang X, Shi Y, He Mi, Tan H, Li X. Ion absorption and distribution of symbiotic Reaumuria soongorica and Salsola passerina seedlings under $\mathrm{NaCl}$ stress. Acta Ecologica Sinica 34, 963-972, https://doi.org/10.5846/stxb201210091392 (2013).

19. Tab H, Li X, Liu Y, Zhao X. Study on the Antioxidative Ability and Salt Tolerance of Reaumuria soongorica Callus under Salt Stress. Journal of Desert Research 33, 549-553, https://doi.org/10.7522/j.issn.1000-694X.2013.00075 (2013).

20. Mutale-joan C, Rachidi F, Mohamed HA, Mernissi NE, Aasfar A, Barakate M, Mohammed D, Sbabou L, Arroussi HE. Microalgaecyanobacteria-based biostimulant effect on salinity tolerance mechanisms, nutrient uptake, and tomato plant growth under salt stress. J Appl Phycol 4, 276, https://doi.org/10.1007/s10811-021-02559-0 (2021). 
21. Ibrahimova U, Kumari P, Yadav S, Rastogi A, Antala M, Suleymanova Z, Zivcak M, Tahjib-Ul-Arif MD, Hussain S, Abdelhamid M, Hajihashemi S, Yang X, Brestic M. Progress in understanding salt stress response in plants using biotechnological tools, Journal of Biotechnology 329, 180-191, https://doi.org/10.1016/j.jbiotec.2021.02.007 (2021).

22. Cai Z, Liu X, Chen X, Yang R, Chen J, Zou L, Wang C, Chen J, Tan M, Mei Y, Wei M. Variations in morphology, physiology, and multiple bioactive constituents of Lonicerae Japonicae Flos under salt stress. Scientific Reports 11, 3939هhttps://doi.org/10.1038/s41598021-83566-6 (2021).

23. Kumar SR, Wang X, Jin D, Zhang H, Gui H, Dong Q, Pang N, Zhang X, Song M. Screening and evaluation of reliable traits of upland cotton (Gossypium hirsutum L.) genotypes for salt tolerance at the seedling growth stage. Journal of Cotton Research 3, 11, https://doi.org/10.1186/s42397-020-00049-1 (2020).

24. Alzahib RH, Migdadi HM, Al Ghamdi AA, Alwahibi MS, Ibrahim AA, Al-Selwey WA. Assessment of Morpho-Physiological, Biochemical and Antioxidant Responses of Tomato Landraces to Salinity Stress. Plants 10,696, https://doi.org/10.3390/plants10040696 (2021).

25. Nguyen HTT, Das Bhowmik S, Long H, Cheng Y, Mundree S, Hoang LTM. Rapid Accumulation of Proline Enhances Salinity Tolerance in Australian Wild Rice Oryza australiensis Domin. Plants 10, 2044, https://doi.org/10.3390/plants10102044 (2021).

26. Heydari M , Sharafi Y , Tabatabaei S J , Hokmabadi H. How Pistachio Hybrid " P. Integerrima $\times$ P. Vera " grows and responses to NaCl salinity. International Journal of Fruit Science 11, 1-14, https://doi.org/10.1080/15538362.2020.1860864 (2020).

27. Nasim NAM, Pa'Ee F. Evaluating physiological responses of Butterfly pea, Clitoria ternatea L. var. Pleniflora to salt stress. IOP Conference Series: Earth and Environmental Science736, 012039, https://doi.org/10.1088/1755-1315/736/1/012039 (2021).

28. Ahmed HAl, Shabala L, Shabala S. Understanding the mechanistic basis of adaptation of perennial Sarcocornia quinqueflora species to soil salinity. Physiologia Plantarum 172, 1997-2010, https://doi.org/10.1111/ppl.13413 (2021).

29. Kumari A, Das P, Parida AK, Agarwal PK. Proteomics, metabolomics, and ionomics perspectives of salinity tolerance in halophytes. Frontiers in Plant Science 6, 537, https://doi.org/10.3389/fpls.2015.00537 (2015).

30. Zhao H, Chen G, Sang L, Deng Y, Gao L, Yu Y, Liu J. Mitochondrial citrate synthase plays important roles in anthocyanin synthesis in petunia. Plant Science 305, 110835, https://doi.org/10.1016/j.plantsci.2021.110835 (2021).

31. Liang X, Liu S, Wang T, Li F, Cheng J, Lai J, Qin F, Li Z, Wang X, Jiang C. Metabolomics-driven gene mining and genetic improvement of tolerance to salt-induced osmotic stress in maize. New Phytologist 230, 2355-2370, https://doi.org/10.1111/nph.17323 (2021).

32. Chao Wang, Yun Xiang, Dong Qian. Current progress in plant V-ATPase: From biochemical properties to physiological functions. Journal of Plant Physiology 266, 153525, https://doi.org/10.1016/j.jplph.2021.153525 (2021).

33. Xu, CX, Zheng L, Gao CQ, Wang C, Liu GF, Jiang J, Wang YC. Ovexpression of a Vacuolar H+-ATPase c Subunit Gene Mediates Physiological Changes Leading to Enhanced Salt Tolerance in Transgenic Tobacco. Plant Molecular Biology Reporter 29, 424-430, https://doi.org/10.1007/s11105-010-0247-4 (2011).

34. Zhao X, Bai X, Jiang C, Li Z. Phosphoproteomic Analysis of Two Contrasting Maize Inbred Lines Provides Insights into the Mechanism of Salt-Stress Tolerance. International Journal of Molecular Sciences 20, 1886, https://doi.org/10.3390/ijms20081886 (2019).

35. Kodama A, Watanabe T, Yamaguchi M, Narita R, Katsuhara M, Sato K, Ookawa T, Hirasawa T. Accession difference in leaf photosynthesis, root hydraulic conductance and gene expression of root aquaporins under salt stress in barley seedlings. Plant Production Science 24, 73-82, https://doi.org/10.1080/1343943X.2020.1794915 (2020).

36. Lin MT, Orr DJ, Worrall D, Parry MAJ, Carmo-Silva E, Hanson MR. A procedure to introduce point mutations into the Rubisco large subunit gene in wild-type plants. The Plant Journal 106, 876-887, https://doi.org/10.1111/tpj.15196 (2021).

37. Wang XJ, Song ZQ, Ti YJ, Liu YX, Li QW. Physiological response and transcriptome analysis of Prunus mume to early salt stress. Journal of Plant Biochemistry and Biotechnology 15,1-13, https://doi.org/10.1007/s13562-021-00680-2 (2021).

38. Panda A, Rangani J, Parida AK. Comprehensive proteomic analysis revealing multifaceted regulatory network of the xero-halophyte Haloxylon salicornicum involved in salt tolerance Journal of Biotechnology. Journal of Biotechnology 324, 143-161, https://doi.org/10.1016/j.jbiotec.2020.10.011 (2020).

39. Sui N, Yang Z, Liu M, Wang B. Identification and transcriptomic profiling of genes involved in increasing sugar content during salt stress in sweet sorghum leaves. BMC Genomics 16, 534, https://doi.org/10.1186/s12864-015-1760-5 (2015).

40. Zhang HH, Shi GL, Shao JY, Li X, Li MB, Liang M, Xu N, Sun GY. Photochemistry and proteomics of mulberry (Morus alba L.) seedlings under $\mathrm{NaCl}$ and $\mathrm{NaHCO}_{3}$ stress. Ecotoxicology and Environmental Safety 184,109624, https://doi.org/10.1016/j.ecoenv.2019.109624 (2019).

41. Mabbitt P, Wilbanks S, Eaton-Rye J. Duplication and divergence of the Psb27 subunit of Photosystem II in the green algal lineage. New Zealand Journal of Botany 52, 74-83, https://doi.org/10.1080/0028825X.2013.859629 (2014).

Page 13/18 
42. Chen C, Cui X, Zhang P, Wang Z, Zhang J. Expression of the pyrroline-5-carboxylate reductase (P5CR) gene from the wild grapevine Vitis yeshanensis promotes drought resistance in transgenic Arabidopsis. Plant Physiology and Biochemistry 168, 188-201, https://doi.org/10.1016/j.plaphy.2021.10.004 (2014).

43. Reddy PS, Jogeswar G, Rasineni GK, Maheswari M, Reddy AR, Varshney RK. Proline over-accumulation alleviates salt stress and protects photosynthetic and antioxidant enzyme activities in transgenic sorghum (Sorghum bicolor (L.) Moench). Plant Physiology and Biochemistry, 94, 104-113. https://doi.org/10.1016/j.plaphy.2015.05.014 (2015).

44. Liu D, He S, Zhai H, Wang L, Zhao Y, Wang B, Li R, Liu Q. Overexpression of IbP5CR enhances salt tolerance in transgenic sweet potato. Plant Cell Tissue Organ Cult 117, 1-16, https://doi.org/10.1007/s11240-013-0415-y (2014).

45. Scharfenberg M, Mittermayr L, Von Roepenack-Lahaye E, Schlicke H, Grimm B, Leister D, Kleine T. Functional characterization of the two ferrochelatases in Arabidopsis thaliana. Plant Cell Environ 38, 280- 298, https://doi.org/10.1111/pce.12248 (2015).

46. Zhang B, Wang $\mathrm{H}$, Zhang Y. SNARE proteins and their role in plant ion channel regulation. Plant Growth Regulation 92 , 443-453, https://doi.org/10.1007/s10725-020-00656-7 (2020).

47. Zhang B, Karnik R, Wang YZ, Wallmeroth N, Blatt MR, Grefen C. The Arabidopsis R-SNARE VAMP721 Interacts with KAT1 and KC1 $\mathrm{K}^{+}$Channels to Moderate $\mathrm{K}^{+}$Current at the Plasma Membrane 27, 1697-1717, https://doi.org/10.1105/tpc.15.00305 (2015).

48. Salinas-Cornejo J, Madrid-Espinoza J, Ruiz-Lara S, Identification and transcriptional analysis of SNARE vesicle fusion regulators in tomato (Solanumly copersicum) during plant development and a comparative analysis of the response to salt stress with wild relatives. Journal of Plant Physiology 242, 153018, https://doi.org/10.1016/j.jplph.2019.153018 (2019).

49. Deisenroth C, Zhang Y. Ribosome biogenesis surveillance: probing the ribosomal protein-Mdm2-p53 pathway. Oncogene 29, 42534260, https://doi.org/10.1038/onc.2010.189 (2010).

50. Wang X, Xiang D, Wang Z, Wang Z, Yang X, Yu S, Pang Q, Liu S, Yan L. Label-free quantitative proteomics analysis of Humulus scandens (Lour.) Merr. leaves treated by an odor compound of Periploca sepium Bunge. Ecotoxicology and Environmental Safety 215 , 0147-6513, https://doi.org/10.1016/j.ecoenv.2021.112131 (2021).

51. Xu C, Sibicky T, Huang B. Protein profile analysis of salt-responsive proteins in leaves and roots in two cultivars of creeping bentgrass differing in salinity tolerance. Plant Cell Rep 29, 595-615, https://doi.org/10.1007/s00299-010-0847-3 (2010).

52. Li W, Zhao FA, Fang WP, Xie DY, Hou JN, Yang XJ, Zhao YM, Tang ZJ, Nie LH, Lv SP. Identification of early salt stress responsive proteins in seedling roots of upland cotton (Gossypium hirsutum L.) employing iTRAQ-based proteomic technique. Frontiers in Plant Science 6, 732, https://doi.org/10.3389/fpls.2015.00732 (2015).

53. Hu S, Zhang J, Zhang Y, He S, Zhu F. Baseline sensitivity and toxic actions of boscalid against Sclerotinia sclerotiorum. Crop Protection 110, 83-90, https://doi.org/10.1016/j.cropro.2018.04.004 (2018).

54. Sajid M, Ahsanullah, Basit A, Ullah I, Shah S, Haleema B, Nawab K, Ahmad I, Ahmad N, Khan A, Muhammad M. Screening of Citrus Rootstocks for Salinity Tolerance Based on Initial Growth Attributes and Leaves Proline Content. Elementary Education Online 19, 3128-3140, https://doi.org/10.17051/ilkonline.2020.04.764688 (2021).

55. Kumaravel M, Uma S, Backiyarani S, Saraswathi MS, Vaganan MM, Muthusamy M, Sajith KP. Differential proteome analysis during early somatic embryogenesis in Musa spp. AAA cv. Grand Naine. Plant Cell Reports 36, 1-16, https://doi.org/10.1007/s00299-0162067-y (2017).

56. Holá D, Benešová M, Fischer L, Haisel D, Hnilička F, Hniličková H, Kočová M, Tůmová L, Wilhelmová N. The disadvantages of being a hybrid during drought: A combined analysis of plant morphology, physiology and leaf proteome in maize. PLoS ONE 12 , e0176121. https://doi.org/10.1371/journal.pone.0176121 (2017).

57. Kumar RR, Singh K, Ahuja S,Tasleem M, Singh I, Kumar S, Grover M, Mishra D, Rai GK, Goswami S, Singh GP, Chinnusamy V, Rai A, Praveen S. Quantitative proteomic analysis reveals novel stress-associated active proteins (SAAPs) and pathways involved in modulating tolerance of wheat under terminal heat. Funct Integr Genomics 19, 329-348, https://doi.org/10.1007/s10142-018-0648-2 (2019).

\section{Figures}



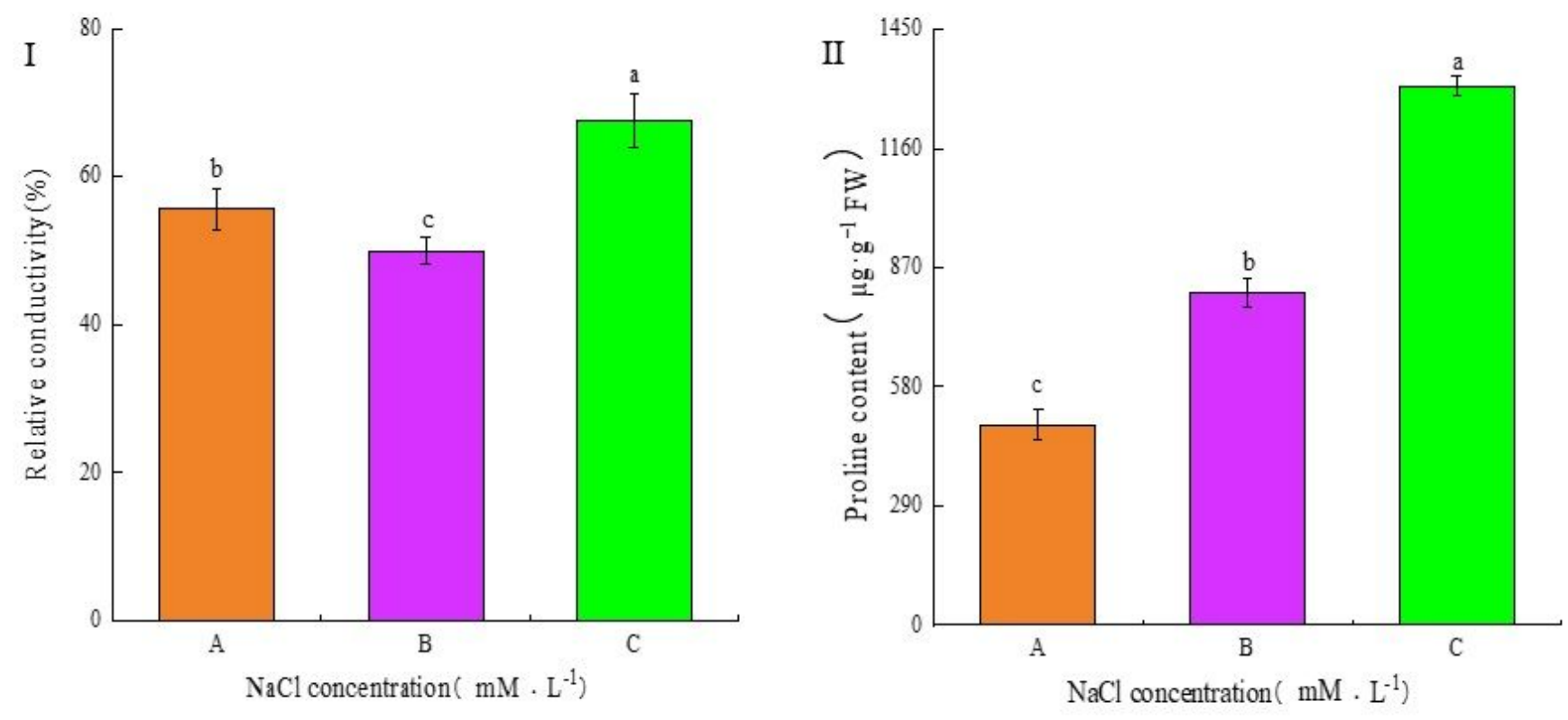

\section{Figure 1}

Effects of concentrations of $\mathrm{NaCl}$ on relative conductivity and proline content of R. soongorica Leaves. I: relative conductivity II: proline content

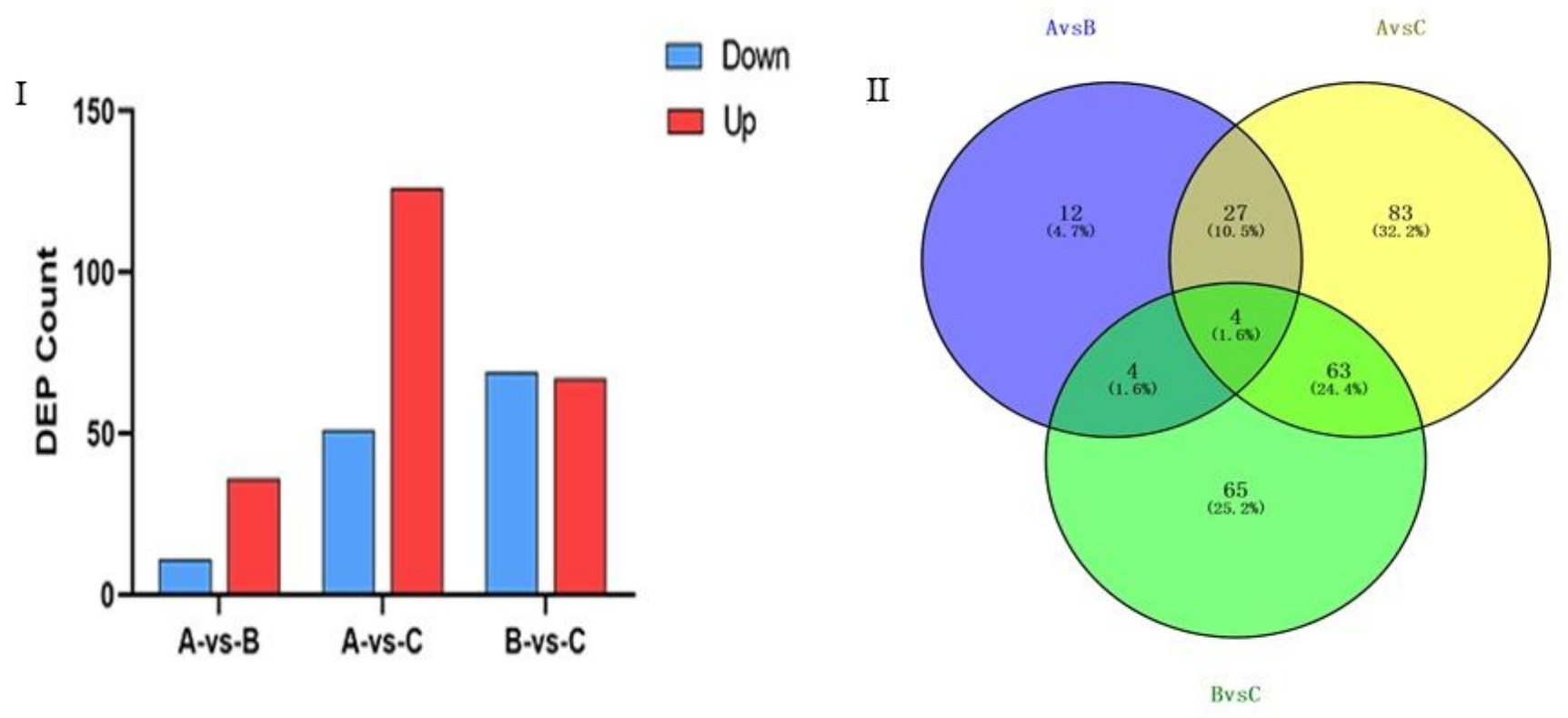

Figure 2

Number of differentially expressed proteins and Venn diagram analysis. Notes: A vs B means compare B with A, A vs C means compare $C$ with $A, B$ vs $C$ means compare $C$ with $B$. The same as below. 
A vs B

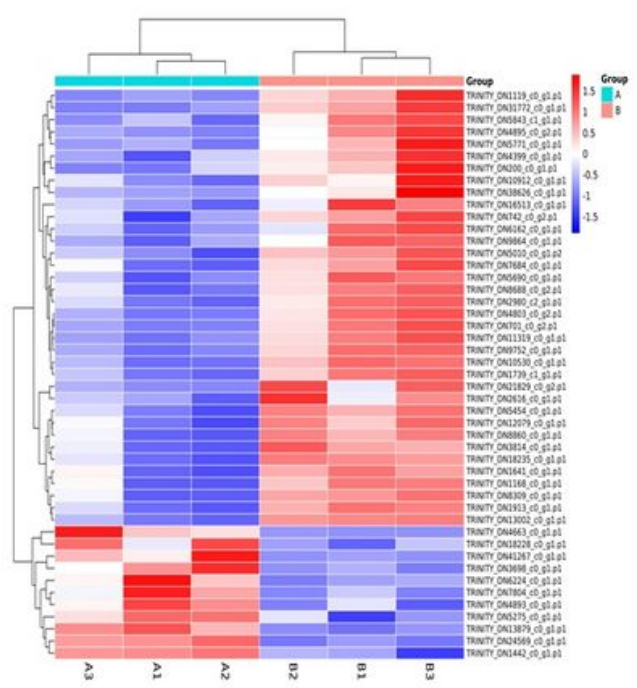

A vs C

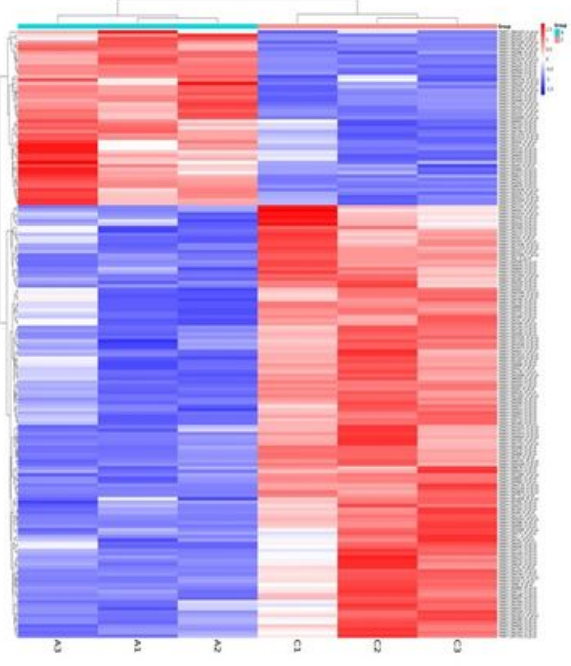

B vs C

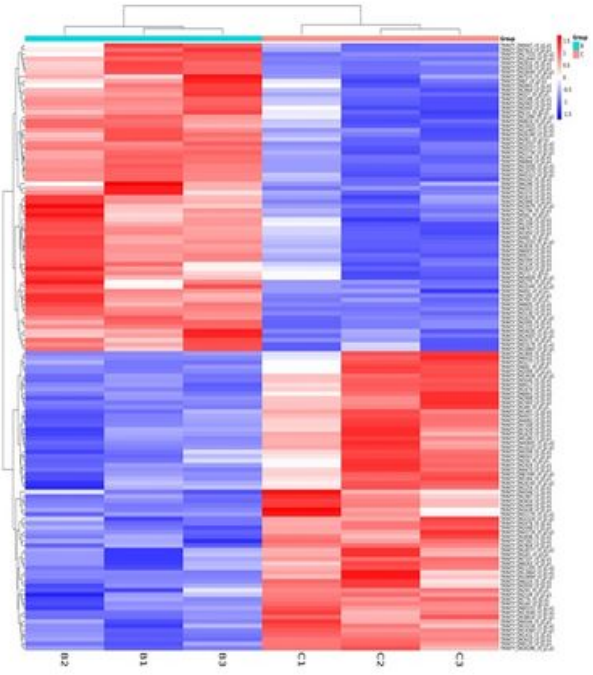

Figure 3

Hierarchical clustering analysis for differentially expressed proteins under salt stress. Notes: The shades of blue reflect the degree of decrease in protein expression, while the shades of red reflect the degree of increase in protein expression

\section{Functional classifications of differentially expressed proteins}

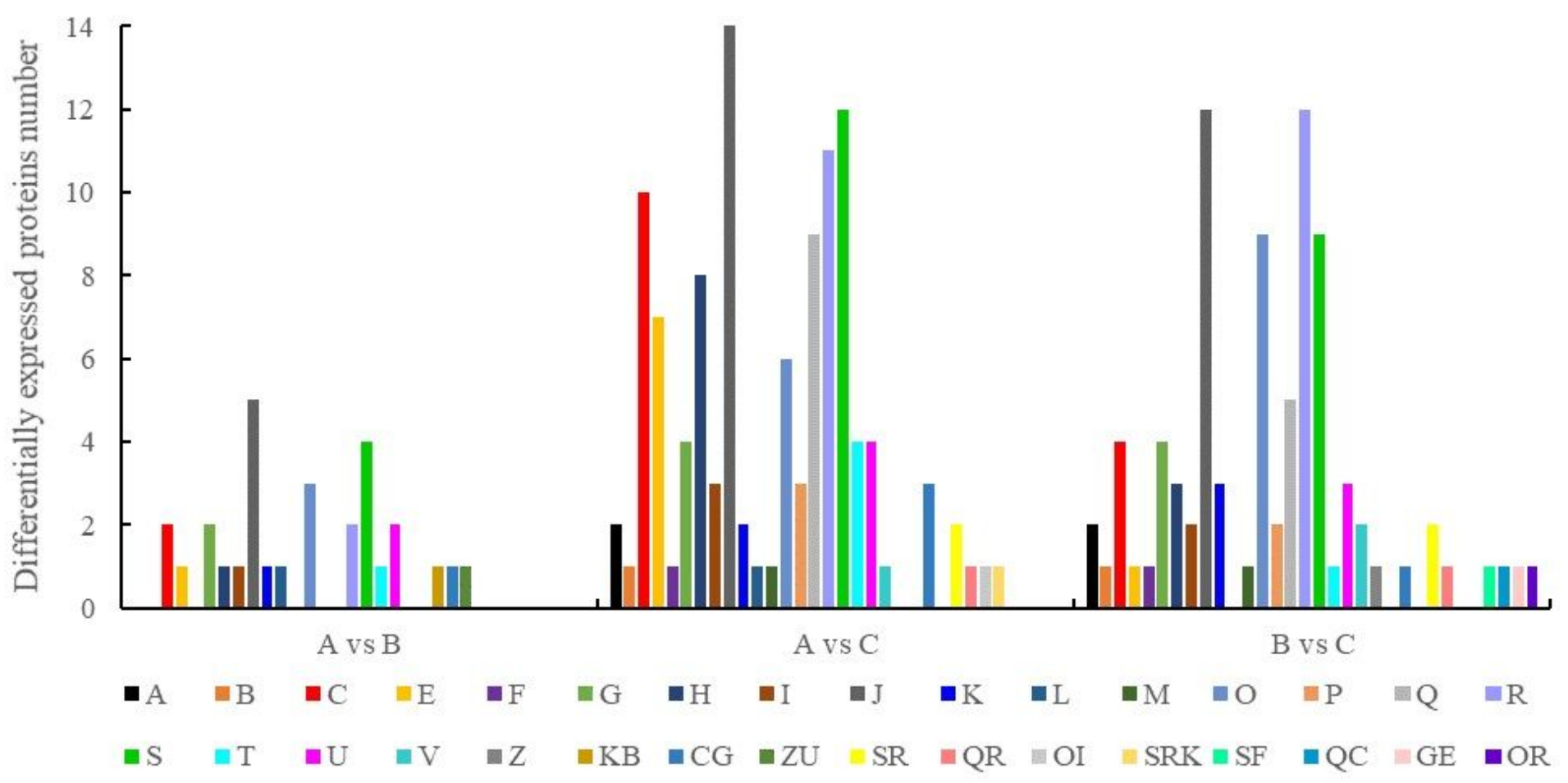

\section{Figure 4}

Functional classifications of differentially expressed proteins. Note: respectively. A: RNA processing and modification; B: Chromatin structure and dynamics; C: Energy production and conversion; E: Amino acid transport and metabolism; F: Nucleotide transport and metabolism; G: Carbohydrate transport and metabolism; H: Coenzyme transport and metabolism; I: Lipid transport and metabolism; J: Translation, ribosomal structure and biogenesis; K: Transcription; L: Replication, recombination and repair; M: Cell wall/membrane/envelope biogenesis; O: Posttranslational modification, protein turnover, chaperones; P: Inorganic ion transport and 
metabolism; Q: Secondary metabolites biosynthesis, transport and catabolism; R: General function prediction only; S: Function unknown; $\mathrm{T}$ : Signal transduction mechanisms; U: Intracellular trafficking, secretion, and vesicular transport; V: Defense mechanisms; Z: Cytoskeleton;

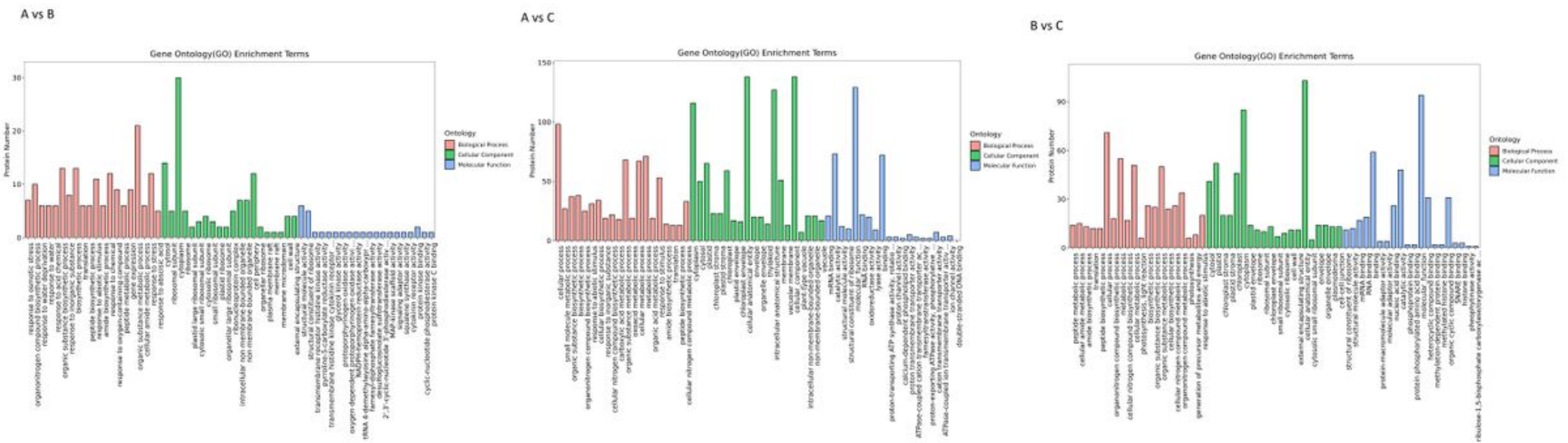

\section{Figure 5}

Gene Ontology (GO) annotation of differentially expressed proteins under the salt stress. Note: The enrichment results in the three categories are shown in the figure, with up to 20 of each.

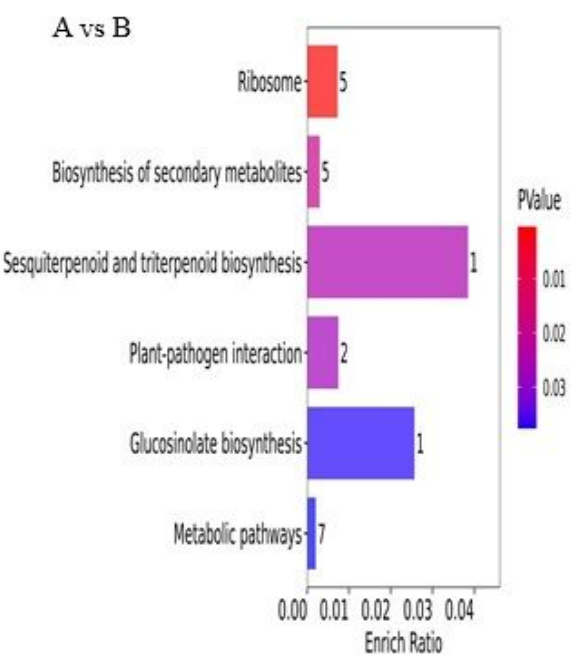

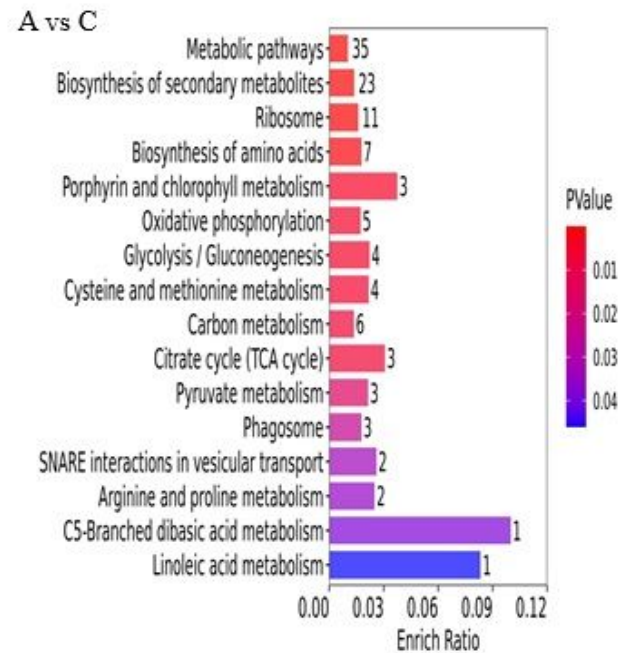

B vs C

$$
\text { Metabolic pathwars: } 23
$$

Biosynthesis of seconday metibolites. 13

Gyycolysis/Guconeogenesis _ $\quad 4$

Guccosinalite biosynthesis -

Photosynthesis

Nitrogen metabolism

SNARE interactions in vesicular transport

Terpenoid backbone biosynthesis

Pyrimidine metabolism Carbon metabolism- 4

Glycine, serine and threonine metabolism 2

Carbon fixation in photosynthetic organisms

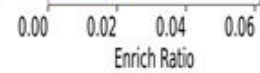

\section{Figure 6}

The bar diagram of differential protein KEGG enrichment results. 

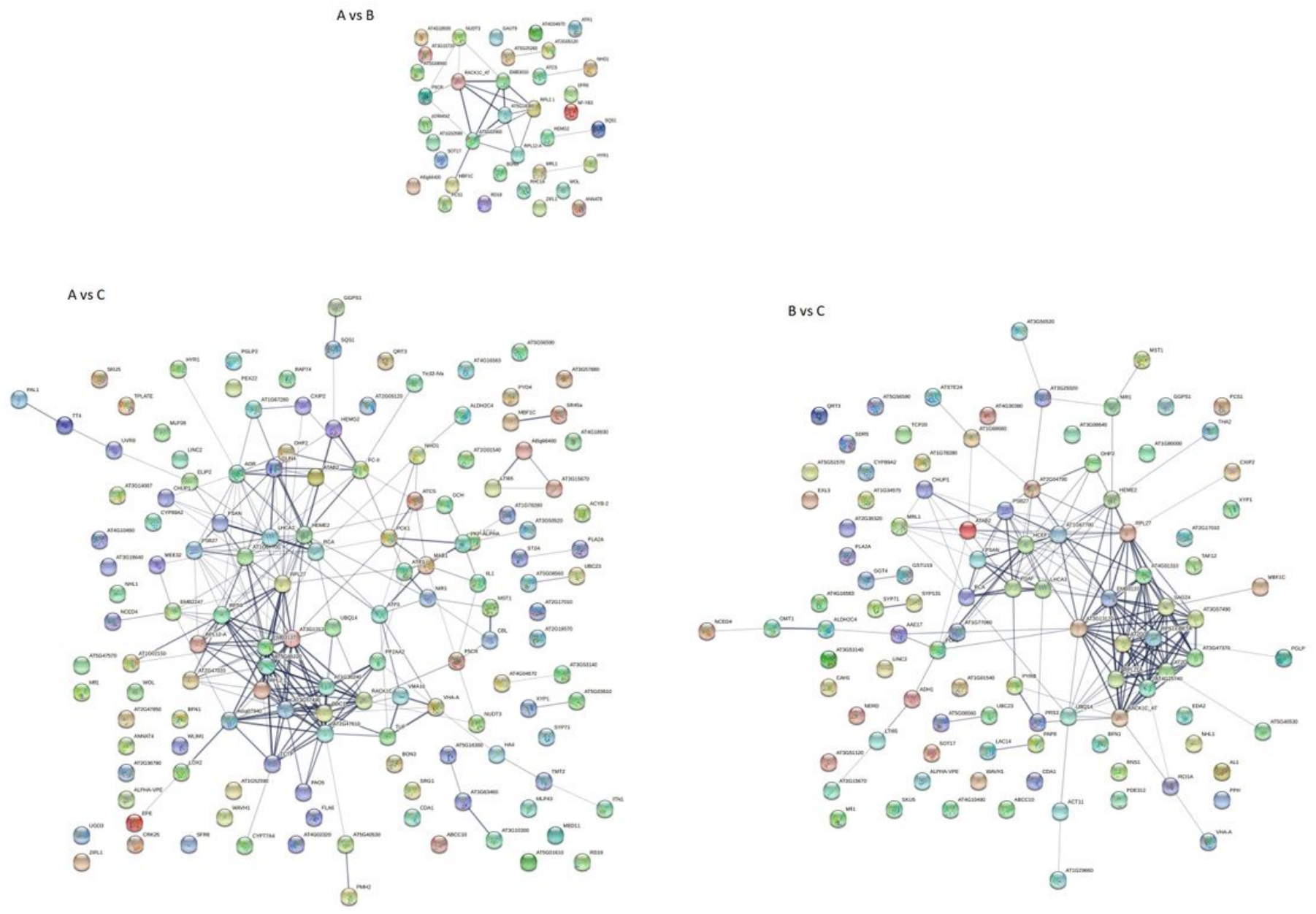

\section{Figure 7}

Protein interaction network diagram. 